\title{
MANAJEMEN STRATEGI KEBIJAKAN PUBLIK SEKTOR PARIWISATA DI DESA PUJON KIDUL KECAMATAN PUJON KABUPATEN MALANG JAWA TIMUR PADA ERA INDUSTRI 4.0
}

\author{
Yohanes Handrianus Laka', Cahyo Sasmito ${ }^{2}$ \\ ${ }^{12}$ Universitas Tribhuwana Tunggadewi \\ andilaka2@gmail.com
}

\begin{abstract}
The tourism sector is a significant sector for increasing regional income. To clarify this, a public policy management strategy in the field of tourism is needed through serious efforts from the regional government. Pujon Kudul Tourism Village Pujon District Malang Regency is one of the important icons of tourism in the region. The aims of this research is 1) Assessing public policy management strategies carried out by Malang Regency government in $\begin{array}{ll}\text { managing the village of Pujon Kidul wisat } & \text { 2) Creating a new moidel strategic management }\end{array}$ for public policy based on the tourism sector 4.0. The research method employs qualitative descriptive analysis with a SWOT analysis tool. The research findings show that the management of the public policy strategy in the tourism sector in Pujon Kudul village has quite significant in increasing regional income, but crucial things are still found quite significant in increasing regional income, but crucial things are still found in the
management of reports and sustainability assets of Pujon Kidul village that are still touched by a strategy model based on the 4.0 industrial revolution. With the new model offer study, it will provide an effective solution in every performance of tourism village ma through an integrated management public policy model.

Keywords: Strategic Management, Public Policy, Tourism Sector, Industrial Revolution 4.0

Sektor pariwisata adalah sektor yang signifikan untuk peningkatan pendapatan daerah. Untuk merelasisikan hal tersebut, dibutuhkan strategi manajemen kebijakan publik bidang sektor pariwisata yang dijalankan melalui upaya serius dari pemerintahan daerah. Desa wisata Pujon Kudul Kecamatan Pujon Kabupaten Malang adalah salah satu ikon penting pariwisata di wilayah tersebut. Tujuan penilitian ini adalah 1) Mengkaji strategi manajemen kebijakan publik yang dilakukan oleh pemerintah Kabupaten Malang dalam mengelola desa wisata Pujon Kidul 2) Mencari model strategi manajemen terbaru untuk kebijakan publik sektor pariwisata berbasiskan revolusi industri 4.0 dalam pengelolan desa wisata pujon kidul. Metode penelitian dengan menggunakan analisis deskriptif kualtitatif dengan alat analisis SWOT. Temuan penelitian menunjukkan bahwa manajemen strategi kebijakan publik sektor pariwisata di desa Pujon Kudul sudah cukup signifikan dalam peningkatan PAD daerah, namun masih ditemukan hal-hal yang krusial dalam pengelolaan laporan dan sustainability aset desa pujon kidul yang masih tersentuh dengan model strategi berbasiskan revolusi industri 4.0. Dengan model baru yang ditawarkan dalam penelitian ini akan memberikan solusi yang efektif dalam setiap kinerja pengelolaan desa wisata melalui model integrated management public policy.
\end{abstract}

Kata Kunci: Kebijakan Publik, Sektor Wisata, Strategi Manajemen, Revolusi Industri 4.0 


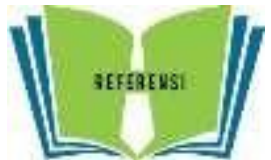

\section{PENDAHULUAN}

Kebijakan publik adalah sebuah upaya pemerintah untuk melayani masyarakat secara luas dan terintegrasi dalam sebuah sistem informasi (Gunawan, 2016: 25). Salah satu sektor yang penting dan merupakan urat nadi perkonomian adalah sektor pariwisata. Berdasarkan kajian dari Yani (2009: 63) menegaskan bahwa keuntungan daerah dapat diperoleh melalui retribusi yang dipungut oleh pemeintah berdasarkan Peraturan Daerah yang telah disahkan oleh pemerintah setempat.

Pemerintah kabupaten Malang telah berupaya memaksimalkan hasil dari anugerah alam yang telah tersedia di wilayah ini, baik di wilayah pantai, pegunungan maupun pertanian. Salah satu usaha keras Pemerintah Kabupaten Malang adalah menyediakan sebuah tempat wisata yang unik dan menarik yaitu di desa Pujon Kidul kecamatan Pujon Kabapaten Malang. Dengan struktur alam yang mendominasi keindahan dan pesona pertanian serta hawa yang sejuk, desa wisata pujon kidul pada tahun 2019 telah menjadi destinasi wisata yang signifikan bagi turis domestik dari berbagai wilayah di Indonesia.

Beberapa peneliti terdahulu yang telah menfokuskan pada pengelolaan dan kebijakan publik sektor pariwisata antara lain Qodriatun (2018), Subarkah (2018), Arliman (2018), Jeong-Keum \& Eun-Sue (2019) \& Dunets, Latysheva \&Bitter (2019) . Mereka lebih memfokuskan penelitan terhadap kondisi lingkungan pariwsata dan kebijakannya serta upaya implementasi kebijakan dalam sektor pariwisata. Namun masih sedikit yang membahas tentang model strategi manajemen kebijakan publik sektor pariwisata. Peneliti lebih menitikberatkan pada model strategi. Di sinilah gap of research tentang model strategi manajemen kebijakan akan diperkaya dalam penelitian ini, khususnya pada sektor pariwisata berbasiskan revolusi industri 4.0.
Adapun tujuan penelitian ini adalah 1) Mengkaji strategi manajemen kebijakan publik yang dilakukan oleh pemerintah Kabupaten Malang dalam mengelola desa wisat Pujon Kidul 2) Mencari model strategi manajemen terbaru untuk kebijakan publik sektor pariwisata berbasiskan revolusi industri 4.0 dalam pengelolan desa wisata pujon kidul.

Penelitian ini juga diproyeksikan untuk meningkatkan pendapatn asli daerah. Pendapatan yang diperoleh dari retribusi dan objek pariwisata ini akan diberikan kepada dinas pariwisata dan sebagai pendapatan asli daerah dari Kabupaten Malang. Pariwisata daerah juga merupakan salah satu penyumbang dalam penerimaan daerah dan pengaruh pendapatan pariwisata terhadap pendapatan asli daerah juga mempunyai peranan yang signifikan dan sangat penting untuk kemajuan perekonomian Kabupaten Malang itu sendiri, oleh karena itu sektor pariwisata dâpat dijadikan studi yang bermanfaat untuk dibahas karena pendapatan asli daerah paling banyak sector pariwisata dalam mendorong perekonomian Kabupaten Malang. Strategi yang digunakan untuk mendorong perekonomian dari retribusi sektor pariwisata dengan cara yang lebih baik dan cepat dalam pengelolaan retribusi dan sektor pariwisata yang dijalankan sesuai dengan peraturan daerah kabupaten malang dan diketahui bahwa pendapatan yang banyak dalam mendorong perekonomian itu sendiri bahwa dari retribusi lebih banyak di bandingkan dengan sektor-sektor yang lain untuk meningkatkan pendapatan perkapita, dan ini terlihat dari kontribusi pariwisata terhadap Pendapatan Domestik Bruto (PDB) nasional dan daya serap lapangan kerja di sektor pariwisata.

\section{TINJAUAN PUSTAKA}

\section{Definisi Manajemen Strategi}

Manajemen strategi merupakan sebagai suatu keputusan dan tindakan yang menghasilkan formulasi dan implementasi 
rencana yang dirancang untuk meraih tujuan suatu perusahaan atau pemerintah (Pearce II \& Robinson, 2008)

\section{Kebijakan Publik}

Kebijakan publik menurut Wilson (2019:17) dalam bukunya "Public Policy" menugaskan bahwa upaya pemerintah untuk melayani masyarakat melalui kebijakan yang dibuat oleh pemerintah baik pusat maupun daerah dalam upaya mensejahterakan masyarakatnya. Kebijakan publik juga kepanjangan dari kewenangan pemerintah dalam negara hukum yang menggunakan asas legalitas dalam konstitusinya sebagaimana yang tertuang dalam pasal 1 ayat 3 UUD 1945 perubahan ketiga mengandung arti bahwa penyelenggaraan pemerintahan harus didasarkan pada undang-undang dan memberikan jaminan terhadap hak-hak dasar rak

Kebijakan publik memusatkan perhatian pada apa yang sebenarnya perlu untuk dilakukan oleh pemerintah melalui berbagai alternatif penentuan langkah yang strategis untuk mencapai sasaran pembangunan. Dunn (2001: 35) mengemukakan bahwa analisis kebijakan publik merupakan sebuah disiplin ilmu sosial terapan yang menggunakan berbagai metode penelitian dan argumen untuk menghasilkan informasi yang relevan dengan kebijakan sehinga bisa dimanfaatkan dalam rangka memecahkan masalah yang terkait dengan implementasi kebijakan.

\section{Sektor Pariwisata}

Di era globalisasi yang bersaing ini dan pasar bebas bahwa, sektor pariwisata diupayakan untuk berkesinambungan di taraf internasional dengan tujuan pemerintah untuk menarik dan juga peningkatan kunjungan wisatawan yang dijadikan sebagai intesitas promosi dan komonikasi dengan pangsa pasar yang teridentifikasi guna meningkatkan pendapatan dari retribusi dan objek wisata. pajak daerah dan retribusi daerah menjadi salah sumber penerimaan yang berasal dari daerah dan dapat dikembangkan sesuai dengan kondisi masing-masing daerah (Gomies dan Pattiasina, 2011). Upaya tersebut harus diawali dengan proses perencanaan berdasarkan informasi bahwa perencanaan harus dilangsungkan sehingga perencanaan berlangsung secara bertahap dan mencapai sasaran secara optimal. Kestabilan pertumbuhan dan perkembangan kepariwisataan di wisata Kabupaten Malang sampai tahun 2015 menunjukkan angka yang cenderung positif. Kondisi ini dikarenakan makin meningkatnya kesadaran dan kepedulian dari kalangan pelaku pariwisata (stakeholders) khususnya pemerintah kabupaten malang, usaha lain masyarakat pemerhati pariwisata seperti pers, lembaga pendidikan, lembaga swadaya masyarakat dan lain sebagainya. Iklim kompetisi yang semakin ketat dan globalisasi memang membutuhkan tenaga kerja yang memiliki ketahanan mental, tanggap terhadap lingkungan, berwawasan luras, dân sekaligus kemampuan beradaptasi yang tinggi menghadapi berbagai perubahan cepat yang terjadi, dari latar belakang di atas mengenai retribusi objek pariwisata kabupaten malang dengan tujuan untuk memberikan kontribusi pada pendapatan asli kota batu. Juga kita ketahui bahwa pendapatan asli daerah itu di dapat peroleh semua penerimaan daerah yang berasal dari sumber ekonomi asli yang salah satunya yaitu retribusi pariwisata. itu juga dengan siapkan strategi yang signifikan dan terbaru untuk mendorong retribusi sektor pariwisata dalam peningkatan pendapatan asli daerah (PAD) Kabupaten Malang. Strategi yang dilakukan dalam mengembangkan pariwisata yang dilakukan oleh pemerintah daerah atau Dinas Pariwisata Kabupaten Malang akan menyediakan sarana dan prasarana agar tidak kalah dengan wisata yang lainnya (Nurhadi, 2008: 281)

Undang-Undang tentang Pemerintahan Daerah yang sudah diubah beberapa kali, terakhir melalui UndangUndang Nomor 23 Tahun 2014 tentang Pemerintahan Daerah mengamanatkan $30 \mid \mathrm{P}$ a g e 
kewenangan khusus lembaga daerah yang dikenal dengan istilah otonomi daerah. Kewenangan ini memberikan keleluasaan bagi pemerintah daerah dalam mengurus sendiri urusan rumah tangganya untuk meningkatkan kesejahteraan masyarakat daerahnya, sesuai dengan kemampuan dan potensi yang dimiliki (Rasyid, 2002:9). Implikasi dari berkembangnya konsep otonomi dalam pelaksanaan pembangunan daerah yaitu bahwa pemerintah daerah memiliki kewenangan untuk mengolah, memanfaatkan, dan mengelola setiap aset dan sumber daya daerah yang potensial untuk diberdayakan agar dapat memberikan kontribusi nyata bagi perkembangan daerah dan peningkatan taraf hidup masyarakat. Pemerintah daerah diarahkan agar mampu menentukan sektorsektor strategis yang dapat mendorong terlaksananya pembangunan di daerah.

Sektor pariwisata merupakan salah satu sektor prioritas dalam pembangunan di Indonesia saat ini karena memiliki prospek yang sangat besar untuk dikembangkan (Pitana \& Gayatri, 2005: 54), Selain itu pembangunan sektor pariwisata diarahkan sebagai pembangunan yang tidak hanya menekankan keuntungan dari aspek ekonomi yang berpeluang membahayakan keberlangsungan sumber daya, akan tetapi pembangunan diarahkan agar adil bagi sosial budaya masyarakat dengan penekanan pada pelestarian lingkungan sehingga menjadikannya sebagai suatu upaya pembangunan yang layak untuk dilakukan di masa sekarang dan yang akan datang.

\section{Revolusi Industri 4.0}

Prof Klaus Schwab, Ekonom terkenal dunia asal Jerman, Pendiri dan Ketua Eksekutif World Economic Forum (WEF) yang mengenalkan konsep Revolusi Industri 4.0. Dalam bukunya yang berjudul "The Fourth Industrial Revolution", Prof Schawab (2017) menjelaskan revolusi industri 4.0 telah mengubah hidup dan kerja manusia secara fundamental. Berbeda dengan revolusi industri sebelumnya, revolusi industri generasi ke-4 ini memiliki skala, ruang lingkup dan kompleksitas yang lebih luas. Kemajuan teknologi baru yang mengintegrasikan dunia fisik, digital dan biologis telah mempengaruhi semua disiplin ilmu, ekonomi, industri dan pemerintah. Bidang-bidang yang mengalami terobosoan berkat kemajuan teknologi baru diantaranya (1) robot kecerdasan buatan (artificial intelligence robotic), (2) teknologi nano, bioteknologi, dan (4) teknologi komputer kuantum, (5) blockchain (seperti bitcoin), (6) teknologi berbasis internet, dan (7) printer 3D.

Revolusi industri 4.0 merupakan fase keempat dari perjalanan sejarah revolusi industri yang dimulai pada abad ke -18. Dunia mengalami empat revolusi industri. Revolusi industri 1.0 ditandai dengan penemuan mesin uap untuk mendukung mesin produksi, kereta api dan kapal layar. Berbagai peralatan kerja yang semula bergantung pada tenaga manusia dān hewân kemudian digantikan dengan tenaga mesin uap. Dampaknya, produksi dapat dilipatgandakan dan didistribusikan ke berbagai wilayah secara lebih masif. Namun demikian, revolusi industri ini juga menimbulkan dampak negatif dalam bentuk pengangguran masa.

\section{METODE}

Jenis Penelitian statistical
descritptive yang akan mengambarkan serta menganalisa bagaimana strategi dan model yang efektif yang digunakan untuk retribusi sektor pariwisata dalam peningkatan pendapatan asli daerah. Di samping itu, penelitian ini juga menggunakan kajian teoritis, komparasi literatur, Tujuan dari penelitian deskriptif ini adalah untuk membuat deskripsi, gambaran, atau lukisan secara sistematis, faktual dan akurat mengenai fakta-fakta, sifat-sifat serta hubungan antar fenomena yang diselidiki.

Sedangkan menurut Sugiyono (2005), menyatakan bahwa metode deskriptif adalah suatu metode yang digunakan untuk menggambarkan atau 
menganalisis suatu hasil penelitian tetapi tidak digunakan untuk membuat kesimpulan yang lebih luas.

Lokasi penelitian merupakan tempat peneliti turun ke lapangan guna melakukan penelitian dan pengambilan data. Lokasi penelitian di lakukan di alamat Deasa Pujon Kidul, Kecamatan Pujon, Kabupaten Malang, Jawa Timur

Alat analisis yang digunakan adalah dengan menggunakan analisis deskriptif kualitatif dan analisis SWOT. Peneliti menguraikan kelebihan, kelemahan dan peluang serta ancaman masing-masing item dalam strategi kebijakan publik tersebut. Data yang diambil adalah dari data sekunder yang diperolah dari laporan pemerintah kabupaten Malang serta sumber buku dan jurnal. Di samping itu peneliti juga mengadakan wawancara dengan beberapa pihak antara lain pengelola desa Pujon Kidul dan Dinas Pariwisata Kabupaten Malang serta masyarakat dan pengguna Desa Pujon Kidul.

\section{HASIL DAN PEMBAHASAN}

\section{Strategi Manajemen Kebijakan Publik sektor pariwisata yang telah dilakukan oleh pemerintah kabupaten Malang}

Setiap destinasi pariwisata harus mempunyai strategi promosi yang baik untuk meningkatkan jumlah kunjungan wisatawan domestik maupun mancanegara, salah satu contohnya ialah pariwisata pedesaan memiliki peluang dalam melakukan pengembangan wisata diantaranya melalui pengembangan atraksi wisata, pengembangan sarana prasarana, pengembangan pemasaran, pengembangan masyarakat.Tujuan pengembangan wisata yang dilakukan untuk meningkatkan kualitas dan kuantitas dari potensi dan sumber daya manusia. Salah satu pengembangan yang dilakukan pada suatu destinasi yaitu desa wisata.

Desa wisata merupakan kawasan pedesaan yang memiliki berbagai macam atraksi wisata. Atraksi wisata tersebut dikemas sedemikian rupa sehingga dapat menarik wisatawan untuk berkunjung dan menetap, menghabiskan waktu berharihari, mengenal lebih dekat budaya desa dan melakukan aktivitas yang dilakukan masyarakat desa. Hadiwijoyo (2012:67) menyatakan bahwa pariwisata pedesaan dapat dilihat sebagai suatu permukiman dengan fasilitas lingkungan yang sesuai dengan tuntutan wisatwan dalam menikmati, mengenal, dan menghayati ke khasan desa dengan segala daya tariknya dan tuntutan kegiatan hidup bermasyarakat. Salah satu pengembangan desa wisata saat ini sudah mulai diterapkan di Jawa Timur khususnya di Kabupaten Malang, di Desa Pujonkidul.

Desa Pujonkidul memiliki potensi wisata yang menarik untuk dijadikan atraksi wisata, diantaranya: wisata alam sumber pitu, agrowisata petik sayur dan buah, wisata outbond, kesenian sandukan, kesenian kuda lumping, sentra olahan susu, dān l wî̀sata edukasi ternak sapi. Berdasarkan pernyataan di atas, Desa Wisata Pujonkidul telah memenuhi karakteristik sebagai sebuah desa wisata. Adapun karakteristik atau kriteria sebuah desa wisata menurut Hadiwijoyo (2012:69), meliputi aksesbilitas baik, memiliki obyek-obyek menarik berupa alam, seni budaya, legenda, makanan lokal, dan sebagainya, masyarakat dan aparat Desa menerima dan memberikan dukungan yang tinggi terhadap desa wisata serta para wisatawan yang datang ke desa, keamanan di desa tersebut terjamin, tersedianya akomodasi, telekomunikasi, dan tenaga kerja yang memadai, beriklim sejuk dan dingin dan berhubungan dengan obyek wisata lain yang sudah dikenal oleh masyarakat luas.

Desa Wisata Pujonkidul merupakan desa wisata yang berpotensi untuk di kunjungi karena memiliki sumber daya alam yang beragam, serta kegiatan unik masyarakatnya. Ada beberapa destinasi yang bisa dikunjungi di Desa Pujonkidul ini seperti wisata kuliner yaitu Cafe Sawah serta wisata edukasi yang memperkenalkan 


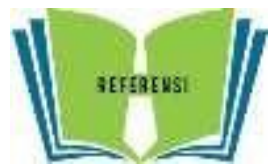

wisatawan bagaimana cara berkebun. Pada hasil pra riset yang dilakukan oleh peneliti keberadaan wisata edukasi ini seolah tertutup dengan obyek wisata yaitu Cafe Sawah dimana wisata kuliner ini terlihat lebih mampu menarik wisatawan untuk berkunjung, sehingga terjadi perubahan besar terhadap masyarakat lokal. Mayoritas wisatawan hanya berkunjung ke Cafe Sawah, hal ini dapat dibuktikan pada data kunjungan wisatawan.

Tabel 1. Jumlah Kunjungan Wisatawan ke Pujonkidul

\begin{tabular}{|l|l|}
\hline Tahun & Jumlah \\
\hline $\mathbf{2 0 1 5}$ & 465 \\
\hline $\mathbf{2 0 1 6}$ & 561 \\
\hline $\mathbf{2 0 1 7}$ & 524 \\
\hline
\end{tabular}

Sumber: Pengelola Desa Wisata Pujonkidul, 2017

Dapat terlihat dari tabel diatas bahwa jumlah kunjungan ke desa wisata Pujonkidul mengalami lonjakan dari tahun 2015 dan 2016 sebesar $81 \%$, untuk tahun 2017 dari awal tahun hingga bulan Agustus 2017 jumlah kunjangan mencapai 524 pengunjung. Peningkatan jumlah kunjungan wisatawan terhadap $\mathrm{F}$ Desa
Wisata Pujonkidul meningkat hampir $100 \%$ merata pada tiap tahunnya, baik pada wisata kuliner maupun wisata edukasinya dan wisata kulinernya menjadi pusat kunjungan yang paling diminati oleh parawisatawan sendiri baik wisatawan lokal maupun wisatawan mancanegara.

Tabel 2. Jumlah Kunjungan Wisatawan ke Café Sawah

\begin{tabular}{|l|l|}
\hline Tahun & Jumlah \\
\hline $\mathbf{2 0 1 6}$ & 26.133 \\
\hline $\mathbf{2 0 1 7}$ & 214.275 \\
\hline
\end{tabular}

Sumber: Pengelola Desa Wisata Pujonkidul, 2017

Dari Tabel 2 merupakan jumlah kinjungan wistawan ke Cafe Sawah, dari tabel tersebut dapat dilihat bahwa Cafe Sawah menjadi pusat kunjungan yang paling diminati dibandingkan dengan destinasi lainnya yang berada di daerah Dewa Wisata Pujonkidul, dapat dilihat pada tahun 2017 jumlah kunjungan wisatawan mencapai 214.275 orang. Menurut Pokdarwis setempat pusat kunjungan yang paling diminati di Desa Wisata Pujunkidul ialah Cafe Sawah, dikarenakan Cafe Sawah sendiri merupakan destinasi baru yang cukup memikat perhatian untuk kunjungan dan banyak terdapat banyak sekali kegiatan yang bisa dilakukan di Cafe Sawah sehingga tidak salah apabila jumlah kunjungnan wisatawan untuk Cafe Sawah menjadi meningkat Menyadari hal tersebut, maka pariwisata sebagai suatu industri memerlukan strategi promosi dengan pola pengembangan kepariwisataan yang terencana secara menyeluruh. Terlebih dengan meningkatkan persaingan di dunia pariwisata pada satu dekade terakhir ini membuat setiap daerah harus mencari terobosan dalam mempromosikan pariwisata guna memiliki nilai jual lebih di mata wisatawan. Kegiatan promosi juga diperlukan identifikasi komunikasi seperti apakah yang diperlukan oleh organisasi atau individu dalam melakukan komunikasi kepada kelompok atau target pasar dalam meningkatkan kunjungan wisatawan. Melalui kegiatan promosi Cafe Sawah di 
Desa Wisata Pujonkidul diharapkan dapat digunakan untuk membantu meningkatkan kunjungan wisatawan terhadap salah satu daerah tujuan wisata khususnya desa wisata di Indonesia. Pembuatan strategi dan media promosi yang baik maka akan meningkatkan kunjungan wisatawan.

Adapun dari straegi yamg etelah dilaksankana oleh pemrimntah kabupatan Malang dalam kebijakan publik bidang pariwisata di desa wisata pujon kudul dengan menggunakan SWOT analysis adalah

Lingkungan Internal

1. Kelebihan

Kelebihan retribusi pariwisata desa pujon kidul memberi kontribusi besar dari total pendapatan asli daerah kabupaten malang hal ini membuktikan bahwa desa pujon kidul kecamatan pujon kabupaten malang adalah desa wisata yang terus berkembang dengan suport dari retribusi sektor pariwisata antara lain dari destinasi tempat wisata, alam yang tersedia misalnya Dengan struktur alam yang mendominasi keindahan dan pesona pertanian serta hawa yang sejuk, desa wisata pujon kidul pada tahun 2019 telah menjadi destinasi wisata yang signifikan bagi turis domestik dari berbagai wilayah di Indonesia.

2. Kelemahan

Kelemahan utama dalam manajemen kebijakan publik adalah pemerintah kabupaten Malang belum memberikan kepastian Perda tentang pengaturan desa wisata. Memang sudah ada Perda No. 20 tahun 2003 tentang Perizinan Pariwisata, namun Perda ini dianggap sudah out of date. Perda tersebut tidak terlalu signifikan sebagai payung hukum pelaksnaan pengelolaan pariwisata di kabupaten malang. Pemeintah kabupaten Malang masih bersifat sporadis dan hanya mementingkan kepentingan sesaat tanpa adanya keberlanjutan pengelolaan desa wisata. Kelemahan itu nampak dari belum ada Perda yang mengatur desa wisata secara jelas baik manajemen pengelola, hasil yang diperoleh untuk PAD berapa persen hingga mekanisme setoran hasil desa wisata Pujon Kidul kepada dinas pendapatan daerah masih belum jelas.

Lingkungan eksternal

3. Peluang

Masih banyak potensi wisata dapat dikembangkan misalnya tempat menginap hotel, dibangun untuk memenuhi permintaan wisatawan yang tidak tertampung

\section{Ancaman}

Ancaman utama dalam upaya pengelolaan desa wisata adalah persaingan yang semakin keta di kabupaten atau kota di sebelah kabupaten Malang yaitu Kota Batu yang sudah terkenal dengan kota wisatannya dan juga kota Malang yang terus mengembangakan wisata. Apabila pengelolanaan manajemen desa wista tidak maksimal dan tidak mengikuti jaman sesuai dengan revolusi industri 4.0 maka dapat dipastikan desa wisata pujon kidul suatu saat akan ditinggal oleh konsumen dan bergeser ke desa wisata lain yang dikelola oleh Kota Batu maupun Kota Malang.

f. Lầri strategi kebijakan pemerintah tersebut masih banyak kekurangan terutama tidak ada sustainabily dan keibjakan publik yang didukung Perda yang jelas tentang pengelolaan desa wisata di Kabuparten Malang.

\section{Model Strategi Manajemen Kebijakan Pbulik sektor Pariwisata berbaiskan Revolusi industri 4.0}

Setelah mengkaji dari uraian sebelumnya, peneliti mengambil garis atau benang merahnya bahwa dalam upaya peningkatan pendapatan asli daerah dari sektor wisata di desa Pujon Kudul tersebut, maka peneliti membuat sebuah model integrated public policy management. Dengan model ini peneliti akan menguraikan dan memberikan solusi kepada pemerintah Kabupaten Malang dalam upaya menjaga kestablikandan dan sustainabilty dari sektor wisata di desa Pujon Kidul Hal ini juga didasari dari wawancara dengan para pemangku kepentingan sektor wisata baik dari perangkat desa di desa pujon kudul, pejabat 
di dinas pariwisata kabupaten Malang, pengusaha dan masyarakat pengguna desa wisata.

Dari wawancara tersebut yang dilakukan selama satu bulan pada bulan April 2019, peneliti mendapatkan analisis kelemahan dan ancaman dari pengelolaan desa wisata antara lain:

1. Kelemahan

Kelemahan utama dalam manajemen kebijakan publik adalah pemerintah kabupaten Malang belum memberikan kepastian Perda tentang pengaturan desa wisata. Pemeintah kabupaten Malang masih bersifat sporadis dan hanya mementinngkan kepntingan sesaat tanpa adanya keberlanjutan pengelolaan desa wisata. Kelemahan itu nampak dari belum ada Perda yang mengatur desa wisata secara jelas baik manajemen pengelola, hasil yang diperoleh untuk PAD berapa persen hingga mekanisme setoran hasil desa wisata Pujon Kidul kepada dinas pendapatan daerah masih belum jelas.

\section{Ancaman}

Ancaman utama dalam upaya pengelolaan desa wisata adalah persiangan yang semakin keta di kabupaten atau kota di sebelah kabupaten Malang yaitu Kota Batu yang sudah terkenal dengan kota wisatannya dan juga kota Malang yang terus mengembangakan wisata. Apabila pengelolanaan manajemen desa wista tidak maksimal dan tidak mengikuti jaman sesuai dengan revolusi industri 4.0 maka dapat dipastikan desa wisata pujon kidul suatu saat akan ditinggal oleh konsumen dan bergeser ke desa wisata lain yang idikeola oleh Kota Batu maupun Kota Malang.

Untuk mengantisipasi dari permasalahan tersebut maka model manajemen strategi kebijakan publik berbasiskan revolusi industri 4.0 adalah sebagai berikut:

\section{MODEL MANAJEMEN STRATEGI KEBIJAKAN PUBLIK SEKTOR PARIWISATA}

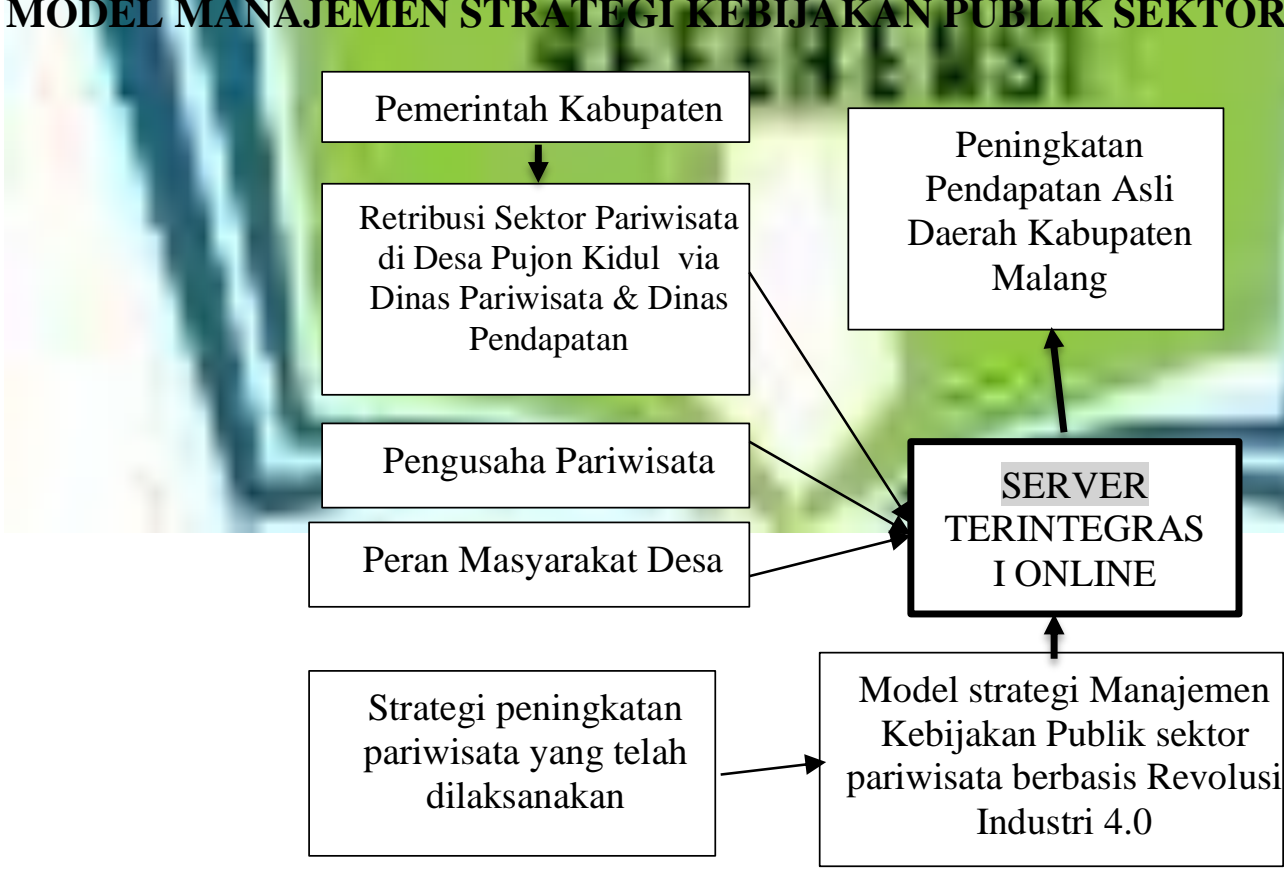

Gambar 1. Model Manajemen Strategi Pariwisata

\section{KESIMPULAN}

1. Menuju realisasi peningkatan PAD di kabupaten Malang, peneliti memfokuskan pada manajemen kebijakan publik pemerintah kabupaten Malang ynng mendorong terciptanya sektor pariwisata di desa Pujon Kudul, Kecamatan Pujon, Kabupaten Malang. Upaya peningkatan PAD masih dirasa kurang maksimal, karena pemreintah kabpaten malang masih memiliki kekurangan di antaranya belum kuatnya Perda yang mengatur pariwisata, 
khususnya desa wisata.. Dengan adanya kelemahan ini maka proses traansaksi retribusi dari pengelolaan pariwisata di desa wisata Pujon Kidul belum mampu memberikan signifikansi yang kuat untuk peningkatan PAD. Hal ini juga dikarenakan belum adanya transparansi dan pengelolaan yang online,sehingga masih banyak kebocoran anggaran dan retribusi.

2. Integrated Public Policy strategic management sektor wisata adalah usulan model yang mengkombinasikan antara laporan dari pelaku usaha di desa wisata Pujon Kidul dan pengawasan oleh Pemerintah kabupaten malang melalui dinas Pariwisata dan dinas Pendapatan, dan masyarakat juga boleh memberikan komentar atau masukan untuk perkembangan yang telah diatur dalam webiste khusus desan pujon kidul yang terintegrasi dengan website pemda kabupaten dan website dinas pariwisa serta dinas pendapatan. Dengan integrasi ini akan memudahkan ropen management serta keberlangsungan pelayanan bidang wisata yang maskimal didukung oleh Perda yang kuat oleh pemkab Malang,

\section{DAFTAR PUSTAKA}

Agus, D: (2017), Manajemen Pelayanan Publik : Peduli, Inklusif, dan Kolaboratif: Gadjah Mada University Press: Yogyakarta.

Arliman, Laurensius. (2018). Peran Investasi Dalam Kebijakan Pembangunan Ekonomi Bidang Pariwisata Di Provinsi Sumatera Barat. Kanun Jurnal Ilmu Hukum. Vol. 20, No. 2, (Agustus, 2018), pp. 273-294.

Dunn, Willian.N (2001) Public Policy Analysis : An Introduction. PrenticeHal,Inc., Englewood Cliffs,N.J.07632. USA.

Dunets, A; Olga Latysheva \& Nataliya Bitter. (2019). The Economic and Infrastructural Basis for the Development of Tourist Space: The Essence, Structure and Typology. Journal of Environmental
Management and Tourism. Vol 10 No. 2, pp. 319-327

Gunawan, Cakti, I. (2015). Sistem Informasi managemen dan $e$ Government. CV.IRDH: Purwokerto.

Gomes, Stevanus J. Dan Victor Pattiasina. 2011. Analisis Kontribusi Pajak Daerah dan Retribusi Daerah Terhadap Pendapatan Asli Daerah di Kabupaten Maluku Tenggara. Aset : Volume 13, Nomor 2, pp 175-183

Hadiwijoyo, Suryo Sakti. (2012). Perencanaan Pariwisata Pedesaan Berbasis Masyarakat. Graha Ilmu: Yogyakarta.

Jeong-Keun Oh \& Eun-Sue You . (2019). Stakeholder perceptions in the government policies on the alternative accommodation industry. Journal of Policy Research in Tourism, Leisure and Events. Vol 11, pp. 276-293

Pemerintah Kabupaten Malang. Peraturan Daerah No. 20 tahun 2003 tantang Perizinan Pariwisata.

Qodriyatün, Sri, N. (2018). Implementasi Kebijakan Pengembangan Pariwisata Berkelanjutan Di Karimunjawa. Aspirasi: Jurnal Masalah-Masalah Sosial. Vol 9, No, 2, pp. 240-259.

Schwab, K. (2017). The fourth industrial revolution. Crown Business Press.

Subarkah, Alwafi Ridho. (2018). Potensi dan Prospek Wisata Halal Dalam Meningkatkan Ekonomi Daerah (Studi Kasus: Nusa Tenggara Barat). Jurnal Sospol, Vol 4 No 2 (Juli-Desember 2018), Hlm 49-72

Sugiyono. (2016) Metode Penelitian Kuantitatif dan Kualitatif QR. Penerbit Alfabeta: Jakarta.

Yani, A. (2002). Hubungan Keuangan Antara Pemerintah Pusat dan Daerah di Indonesia, PT Raja Grafindo Persada, Jakarta.

Wilson, C.A. (2019). Public Policy. Waveland Press, Incorporated: USA. 